\title{
View At The Partner's Transfer Of The Stake And Its Restrictions
}

\author{
Adriána Palajová
}

\section{Faculty of Law, Pavol Jozef Šafárik University in Košice, Slovakia email: adriana.palajova@gmail.com}

PALAJOVÁ, Adriána. View At The Partner's Transfer Of The Stake And Its Restrictions. International and Comparative Law Review, 2015, vol. 15, no. 1, pp. 129-140. DOI: 10.1515/iclr-2016-0031.

\begin{abstract}
This article deals with the transfer of stake in a general commercial company and the transfer of business share in a limited liability company especially according to Slovak legislation and also according to older and current Czech legislation. The attention is focused on the regulation of these transfers and the relations that are generated on the basis of author's point of view and case law. The question of the admissibility and prohibition of the transfer of stake is presented in general commercial company. Analysis of the issue focuses mainly on the formal and material conditions of transfer of business share in limited liability company with differentiation on another member and on third party. Special attention is paid to the consent to that transfer granted by the general meeting or by other body of limited liability company and also is paid to the legal consequences that arise in the case of withholding of consent. The authoress seeks to point at the shortcomings of assessed legal arrangement and provides possible legislative solutions of transfer of stake or business share within the dispositive provisions of the Slovak Commercial Code.
\end{abstract}

Keywords: stake, business share, transfer, general commercial company, limited liability company, member, partner, third party, restrictions of transfer, conditions for transfer, consent of general meeting, free transferability of business share, common certificate

\section{Transfer of stake in general commercial company}

L. Baňacká ${ }^{2}$ states that the admissibility of the transferability of stakes is questionable in a general commercial partnership. The basic argument according to the author against the transferability of stake is the personal nature of the general commercial partnership, in which is becoming linked personal knowledge, experience and thus to networking of stake with its owner and to an accen-

1 External doctoral student, Department of Commercial Law and Business Law, Pavol Jozef Šafárik University in Košice - Faculty of Law, Slovakia, e-mail: adriana.palajova@gmail. com.

2 See Suchoža, J. - Husár, J. et al. Obchodné právo. 1. vydanie, Bratislava: IURA EDITION, 2009, p. 395. 
tuation of continuance partner's in the company. Proponents of transferability argue (relying on the constitutional principles - article 2, sec. 3 Slovak Constitution $^{3}$ ) that the legislation does not prohibit the transfer of stake, therefore it must be accepted. Condition for the transfer of stake will be consent of such majority of partners, which is required to change of the memorandum of association, because the change in the person of partner in this case is the reason for changing of memorandum of association (and for fulfilling the requirement in $\$ 83$ Slovak Commercial Code ${ }^{4}$, this means that at least two partners stay in general commercial partnership).

I. Štenglová ${ }^{5}$ stresses that $\$ 116$ Czech Business Corporations Act $^{6}$ prohibits the transfer of stake in the general commercial partnership explicitly, but even previous legal arrangement in Czech Commercial Code ${ }^{7}$ didn't allow it (even though it did not state explicitly). Explanatory statement to $\$ 116$ Czech Business Corporations Act only notes that the stake transfer is prohibited, furthermore notes that "it does not exclude a more or less cesia of contract according to the Czech Civil Code ${ }^{8 ”}$. It results from $₫ 32 \mathrm{sec}$. 3 Czech Business Corporations Act that the stake in general commercial partnership is not possible to pledge. Although Czech Business Corporations Act prohibits the transfer of stake in general commercial partnership, however it admits some other ways to end the participation of shareholder in this company (eg. by agreement about change of memorandum of association; notice of partner's withdrawal; notice of withdrawal submitted by partner's heir; exclusion of partner for the delay in fulfilling the duty of contribution (for more see Czech Business Corporations Act). The Supreme Court of the Czech Republic commented on inability of stake transfer in general commercial partnership equally: „It can not occur to change in persons of partners by entering into the memorandum of association about stake transfer in the general commercial partnership. ${ }^{\text {"9 }}$

\section{Transfer of business share in limited liability company}

Czech jurisdiction emphasizes that „Business share of member in the limited liability company wound-up with liquidation is possible to transfer until the point of extinction. ${ }^{10} \mathrm{~B}$. Havel ${ }^{11}$ notes that it foresees the free transferability of

3 Act no. 460/1992 Coll. Constitution of Slovak republic as amended by Act no. 306/2014 Coll.

4 Act no. 513/1991 Coll. Commercial Code as amended by Act no. 352/2013 Coll.

5 See Štenglová I. et al. Zákon o obchodních korporacích. Velký komentár. 1.vydání, Praha: C.H.Beck, 2013, p. 248.

6 Act no. 90/2012 Coll. on Commercial Companies and Cooperatives (Business Corporations Act)

7 Act no. 513/1991 Coll. Commercial Code as amended by Act no. 351/2011 Coll.

8 Act no. 89/2012 Coll. Civil Code

9 Uznesení Nejvyššího soudu České republiky, sp. zn. 29 Cdo 646/2008

10 Czech case law: R 66/2002

11 See Štenglová I. et al. Zákon o obchodních korporacích. Velký komentár. 1.vydání, Praha:

(c) Palacký University Olomouc, Czech Republic, 2015. ISSN 1213-8770 (print), ISSN: 2464-6601 (online). 
business share between existing members similarly with the existing Czech legislation, but in the new one without mandatory involvement by the general meeting. Czech Business Corporations Act assumes that limited liability company is more closed company. Legal adjustment of the transfer of business share in limited liability company was dispositive in Czech Commercial Code, therefore it allowed a range of solutions derogating from the legal regulation, for example designation that the general meeting agreement does not grant the approval, but the members themselves or another body of the company (executive directors, supervisory boards); expulsion need of the approval by the general meeting or other body of company whether members themselves, exclude the possibility of transfer to another member at all.

L. Baňacká ${ }^{12}$ presents admissible idea of the transfer of business share, which memorandum of association does not permit, but all members agree with this transfer. The authoress states the restrictions on the transferability of the business shares resulting from the act, memorandum of association or from decision-making practice of courts. She defines the restrictions determined by the memorandum of association those relating to the characteristics of the acquirer or temporal restrictions. She emphasizes that is needed to respect the principle of equal treatment with members. She also focuses on the grant of consent of the general meeting with the transfer of business share. According to her, it is sufficient if the general meeting approves the person of acquirer and the size of the transferred business share. She points to the moment of the conferment of such consent and even that it may be conditional. She presents also the various opinions on the needed majority of votes, by which consent to the transfer of business shares should be given.

D. Hanes ${ }^{13}$ states that the conditions for the transfer of business shares specified in the memorandum of association may be of a different kind, namely substantive or formal. The memorandum of association can provide as condition for the transfer of business share the fulfillment of contribution for registered capital made in full or a certain amount. It can identify the group of persons to whom is possible to transfer business share (eg. in small family companies to family members or persons who carry some kind of trades, to limit at residents or non-residents and the like. Memorandum of association may bind the transfer at company's consent, thus at consent of its statutory bodies - executive directors or resolution of the general meeting of the company or the resolution adopted in the contract by determined qualified majority, it may state that the consent must be granted by all members or only by certain members).

C.H.Beck, 2013, p. 399.

12 See Baňacká, L. Prevoditel’nost' obchodného podielu - 1. čast'. In Bulletin slovenskej advokácie. 2009, č. 1-2, ISSN 1335-1079, p. 17-25.

13 See Hanes, D. Spoločnost’ s ručením obmedzeným. Druhé prepracované vydanie. Bratislava: IURA EDITION, 1996, p. 9 
Even Czech Business Corporations Act according to B. Have ${ }^{14}$ is based on this that the transfer may be conditional what indicate the fact that it may be otherwise limited or made conditional. However, if this change should occur over the duration of the company, it is required the consent of all the members or those who are affected by the change ${ }^{15}$, because the change in the person of member always result to the change of the memorandum of association.

Transferability can be modified according to the current Czech legal arrangement of Business Corporations Act not only by memorandum of association, therefore by rules which are aplicable to all the members, but also by mutual contracts between the members. To the transfer restriction in company with sole member ${ }^{16}$. The $\$ 777 \mathrm{sec}$. 4 Czech Business Corporations Act supposes because it is the change of the existing dispositive rule, that the previous legislation becomes part of the memorandum of association and it will valid even after the effect of the Act.

The issue of granting consent to the transfer can be demonstrated to the approval of the general meeting ${ }^{17}$. Czech jurisdiction expresses following view to granting of the general meeting approval to the transfer of business share that "The consent of the general meeting with the transfer of the part of business share includes also consent to the division of business share, which part is transferred, even when it is not referred explicitly in the resolution of the general meeting. " ${ }^{18}$ Conclusion of contract and approval of the general meeting are two legal facts that must occur in order that business share could be transferred to the transferee. If one of them is missing, the legal effects can not occur. Consent may be given before the conclusion of the transaction contract, it can also go on a subsequent consent. Even Czech jurisdiction expresses the opinion that "If the act requires the consent of general meeting to effectiveness of legal action, approval may be given (if isn 't required by act prior approval), before and after the conclusion of the contract. ${ }^{\text {"19 }}$ General meeting should grant consent according to M. Valachovič for reasons of legal certainty prior to the conclusion of

14 See Štenglová I. et al. Zákon o obchodních korporacích. Velký komentár. 1.vydání, Praha: C.H.Beck, 2013, p. 399.

15 See $\$ 171 \mathrm{sec} .2$ letter b) Business Corporations Act.

16 See $\$ 14$ Business Corporations Act.

17 For adoption of decision of the general meeting about granting of consent to the transfer of business share is sufficient a simple majority of votes of present members ( $\$ 125$ sec.1 letter a) Slovak Commercial Code). Also the Czech Commercial Code in $₫ 141 \mathrm{sec}$. 1 stated that the decision under the provisions of $\$ 113, \S 115$ and $\$ 117$ was not considered for decision on the change of content in memorandum of association, therefore the simple majority of present members was sufficient for granting of consent. See Palajová A. Konsenzus s vybranými zmluvami v obchodných spoločnostiach. In Zborník z medzinárodnej vedeckej konferencie Konsenzus v práve. Banská Bystrica: Univerzita Mateja Bela - Právnická fakulta, 2013. p. 294.

18 Czech case law: SJ 3/1999

19 Rozhodnutí Nejvyššího soudu České republiky, sp. zn. 29 Odo 1278/2005 
the contract. We deem appropriate that the parties entered into a contract with a suspensive or resolutive condition in the case of subsequent approval of the transfer of business share.The general meeting may refuse to give consent for any reason, or it won't be discussed the issue at all. Slovak Commercial Code does not specify any period within which the general meeting may decide to grant consent to the transfer, it is not fully understood as compared to the legal fiction of giving consent to the transfer of shares $(\$ 156 \mathrm{sec}$. 9 Slovak Commercial Code - if the competent authority doesn't decide on the request of the shareholder about granting the consent within the period prescribed articles it is true that the consent was granted). Therefore, we recommend this fiction to lay down at least to the memorandum of association. Parties should think of all the possible negative consequences, which may occur in relation to compliance with the for$\mathrm{mal}$ and material conditions for the transfer, already in the formulation of the contract on transfer of business share. ${ }^{20} \mathrm{~B}$. Havel ${ }^{21}$ considers the second sentence of $\$ 207$, sec. 2 Czech Business Corporations Act for mandatory (due to the construction of the act), if conditional transfer by the consent of company's body is agreed, it will be always concurrently condition for the effectiveness of transfer of business share. However, if the transfer is conditional otherwise than by consent of company's body this rule will not be applied. The act does not assume that the general meeting should approve the contract, it may approve only the fact of the transfer, the contract itself is a thing of the parties and it is delivered the company under $₫ 209$ sec. 2 Czech Business Corporations Act.

Current rules governing for period of granting consent by body Ltd. with the transfer of business share and the consequences of its refusal are dispositive in Czech Business Corporations Act. If is not consent granted within a period of six months from the date of the conclusion of the contract on transfer, the effects occur like when contract is repudiated, unless it is in the contract on transfer of business share specified otherwise. ${ }^{22}$ The contract may also include an arrangement that not granting of consent till a certain period entitles any of the parties withdraw from the contract. Contract is canceled at the moment of delivery of expression of party, who repudiates the contract to another party. All rights and obligations under the contract are terminated and the party to whom was granted performance before the repudiation the contract, is obligated to return this performance. Obligation to compensation for damage in this situation will not arise unless the repudiation is not a reaction to the breach of contractual obligation one of the contractual parties. If, however the approval is not granted

20 See Palajová, A. Konsenzus s vybranými zmluvami v obchodných spoločnostiach. In Zborník z medzinárodnej vedeckej konferencie Konsenzus v práve. Banská Bystrica: Univerzita Mateja Bela - Právnická fakulta, 2013. p. 295.

21 See Štenglová I. et al. Zákon o obchodních korporacích. Velký komentár. 1.vydání, Praha: C.H.Beck, 2013, p. 399.

22 See B. Havel In Štenglová I. et al. Zákon o obchodních korporacích. Velký komentár. 1.vydání, Praha: C.H.Beck, 2013, p. 399. 
and it is caused due to the inaction of the one contractual party, even if the contract stipulated the obligation seeking to obtain consent, legal obligation will be breached and thus it will be given also the basic prerequisite for formation of right to compensation for damage. ${ }^{23}$ If the consent of the company's authority was not granted under Czech Business Corporations Act, the contract on transfer of business share would be ineffective. It means that member did not transfer it and he can withdraw from a company with procedure pursuant to $\$ 164$ Czech Business Corporations Act - by written notice if he fulfilled completely his obligation of contribution. ${ }^{24}$ The contract on transfer of business share may be concluded also with a suspensive condition in relation to grant the mentioned consent. ${ }^{25}$ I. Fekete ${ }^{26}$ adds that it could be the payment for the transfer of business share.

Czech Business Corporations Act provides relative invalidity of the legal acts in $\$ 48$, follows: Legal acts taken without the consent of the supreme body of the business corporation in cases where such consent is required by law shall be invalid. Such invalidity may be claimed within six months after the date when the authorised person became aware or should and could have become aware of such invalidity, but no later than within ten years after the date when such act took place. In our opinion, legal arrangement in $₫ 48$ Czech Business Corporations Act will not be applied to $\$ 207 \mathrm{sec}$. 1 Czech Business Corporations Act (transfer of business share to another member) because granting of consent by the the supreme body of the business corporation (of limited liability company) is conditional by memorandum of association and it is not stated by Czech Business Corporations Act (as in $\$ 48$ Czech Business Corporations Act).

If the transfer of business share was bound with the use of the dispositive nature of $\$ 115 \mathrm{sec}$. 1 Czech Commercial Code for approval of all members alternatively executive directors or supervisory board or other company's body, memorandum of association would determine what procedure consent will be granted. General provisions of $\$ 66 \mathrm{sec}$. 4 Czech Commercial Code shall be applied for decision of company's body when is absence of any such legal adjustment. The need of notarial registration about the decision of company's body alternatively about members approval is controversial - it would have to be inferred on the basis of analogous application of $\$ 141 \mathrm{sec}$. 1 Czech Commercial

23 See Pokorná, J. - Kovařík, Z. - Čáp, Z. et al. Obchodní zákoník. Komentář. I.díl. Praha: Wolters Kluwer ČR, a.s., 2009, p. 540-541.

24 See B. Havel In Štenglová I. et al. Zákon o obchodních korporacích. Velký komentár. 1.vydání, Praha: C.H.Beck, 2013, p. 400.

25 See Pokorná, J. - Kovařík, Z. - Čáp, Z. et al. Obchodní zákoník. Komentář. I.díl. Praha: Wolters Kluwer ČR, a.s., 2009, p. 540-541.

26 See Fekete I. Spoločnost' s ručením obmedzeným. Bratislava: EPOS, 2004. p. 284. 
Code; $\$ 62$ et seq., or $\$ 80$ a Czech Notarial $\operatorname{Code}^{27}$, however, does not prevent the execution of notarial registration. ${ }^{28}$

I. Štenglová ${ }^{29}$ emphasizes that consent to the transfer of business share to another member should be granted (for legal certainty parties) by the general meeting before the conclusion of the contract on transfer of business share. It is possible to allowed also subsequent approval. Prior to the amendment of Czech Commercial Code $\mathrm{C}^{30}$ it was not uniform opinion in the literature as to whether the decision making of the general meeting under the provisions $\$ 125 \mathrm{sec}$. 1 letter d.) the Czech Commercial Code, when it leads by this decision to the change in the content of the memorandum of association, specifically in the part regulating the amount of members contributions or the decision making according to $\$ 125 \mathrm{sec}$. 1 letter j.) Czech Commercial Code ${ }^{31}$. The decision on this issue was very important, because while it was sufficient under $\$ 127 \mathrm{sec}$. 3 Czech Commercial Code for adoption of decision under $\$ 125 \mathrm{sec}$. 1 letter j.) Czech Commercial Code simple majority votes of present members, unless memorandum of association provided exceed number of votes for adoption of decision under $\$ 125 \mathrm{sec}$. 1 letter d) Czech Commercial Code, it was required qualified majority of votes according to $\$ 127 \mathrm{sec}$. 4 Czech Commercial Code. This problem has removed mentioned amendment by explicit provision $\$ 141 \mathrm{sec}$. 1 Czech Commercial Code, according to which the decision under the provisions $₫ 113$, $\$ 115$ and $\$ 117$ Czech Commercial Code did not consider for purposes of determining the required majority of votes for deciding to change the content of the memorandum of association. Decisions under $\$ 113,115,117$ Czech Commercial Code however, had to be in the form of a notarial deed.

The Slovak Commercial Code allows the possibility of transfer of business share with the approval of the general meeting to another member, unless the memorandum of association provides otherwise ${ }^{32}$. Pursuant to L. Baňacká's opinion ${ }^{33}$ so Slovak Commercial Code may allow "increase of business share" of some member without the consent of the general meeting, but also to require fulfillment of any other assumption. The authoress argues that the mentioned provision can be interpreted also in this way that the memorandum of association may exclude the transfer of business share, which would mean the closure of the company and "committal" of member in this company. Like

27 Act no. 358/1992 Coll. Notarial Code

28 See Pokorná, J. - Kovař́k, Z. - Čáp, Z. et al. Obchodní zákoník. Komentář. I.díl. Praha: Wolters Kluwer ČR, a.s., 2009, p. 540-541.

29 See Štenglová, I. - Plíva, S. - Tomsa, M. Obchodní zákoník : komentář. 9. vyd. Praha: C.H. Beck, 2009. p. 366.

30 Act no. 370/2000 Coll.

31 After mentioned amendment letter n.).

32 It is $\$ 115$ sec. 1 Slovak Commercial Code.

33 See Baňacká, L. Prevoditelnost' obchodného podielu - 1. čast'. In Bulletin slovenskej advokácie. 2009, č. 1-2, ISSN 1335-1079, p. 17-25. 
this it may be in the case if the transfer of business share is bound to the fulfillment of unrealistic conditions or difficult to achieve. Currently, we distinguish between the transfer of business share within the company - to another member or outside of company - at the extranea.This latter transfer is possible if it is expressly authorized by the Memorandum of Association and especially when there is a reason to require approval of the general meeting to the transfer of business share.

The possibility of transfer of business share to a third party must be under I. Štenglová expressly provided in the memorandum of association. It is not necessary that such a possibility was regulated in memorandum of association from the beginning. Members, alternatively the general meeting may modify such a change in the agreement on the amendment to the memorandum of association, possibly in the resolution of general meeting on the amendment to the memorandum of association. According to the I. Štenglová's opinion from the diction of $\$ 115 \mathrm{sec}$. 2 Czech Commercial Code it deduces that consent of the general meeting to the transfer of business share is required only if there is a need of this consent provided for in the memorandum of association. She indicates further to this that, if all the members or their legal predecessors expressed the general consent to the transfer of business share to the third parties without any restriction in the memorandum of association, there is no real reason to construct need of approval granted by the general meeting for such transfer. ${ }^{34} \mathrm{Till}$ the memorandum of association has no provision on the transfer of business shares to a third party, respectively it does not allow, then it is not possible. However, the Supreme Court of the Slovak Republic ${ }^{35}$ said: "If the memorandum of association didn't contain the arrangement the possibility of transfer of business share to a third party, but the transfer was effected with the consent of all members, it can not be invalid such a transfer this just because it does not allowed by memorandum of association." The Supreme Court of the Slovak Republic explains that the memorandum of association express the common will of the members and all members have jointly the right to change it that way, that they will proceed in the specific issue will differing to its legal arrangement. ${ }^{36}$ Similarly, the transfer of business share to the extranea under the new Czech Business Corporations Act from B. Havel's view ${ }^{37}$ records changes compared with existing Czech legal arrangement because it supposes essentially the possibility to transfer the business share, but always with the consent of the general meeting. This rule is dispositive and so transfer can be conditional or otherwise make it completely

34 See Štenglová, I. - Plíva, S. - Tomsa, M. Obchodní zákoník : komentár. 9. vyd. Praha: C.H. Beck, 2009. p. 367.

35 Rozsudok Najvyššieho súdu Slovenskej republiky, sp. zn. Obdo V 79/2003.

36 See Palajová, A. Konsenzus s vybranými zmluvami v obchodných spoločnostiach. In Zborník z medzinárodnej vedeckej konferencie Konsenzus v práve. Banská Bystrica: Univerzita Mateja Bela - Právnická fakulta, 2013. p. 294.

37 See Štenglová I. et al. Zákon o obchodních korporacích. Velký komentář. 1.vydání, Praha: C.H.Beck, 2013, p. 400-401. 
opened. We conclude similarly as in $\$ 207 \mathrm{sec}$. 2 Czech Business Corporations Act that if the company decides to make the transfer of business share to a third party conditional by consent of the general meeting, the second sentence of $\S$ 208 sec. 1 Czech Business Corporations Act will be mandatory (Contract on the transfer of business share shall not enter into force before the approval will be granted). If the consent is not required under the memorandum of association or if the transfer is conditional in another way, this rule will be not apply.

Considering that the approval of the general meeting is determined by law in this case, we think that the adjustment mentioned in $\$ 48$ Czech Business Corporations Act could be applied to $\$ 208$ Czech Business Corporations Act (transfer of business share to a person who is not member). If, however, the general meeting shall not grant consent, the contract on transfer of business share shall not enter into effect before the consent has been granted and then this case can not be subordinated under $₫ 48$ Czech Business Corporations Act. Where the consent is not granted within 6 months after the execution date of the contract on transfer of business share, it shall have the same effect as a withdrawal from the contract, unless provided otherwise in the contract on transfer of business share e.g. this, if the contractual parties exclude these effects expresilly in the contract. Then it would be the contract on transfer of business share still valid but ineffective. If the transferor does not get the consent of the general meeting with the transfer of business share, the contract on the transfer of business share never shall enter into effect. Any contractual party will be able to withdraw from contract on transfer of business share for frustration of purpose in the future. The company, respectively third person (who is not member and business share should be further transferred on him/her and paid deposit to the transferee) will not have a simple possibility to invoke the invalidity of a contract on the transfer of business share. This situation, in connection with the withdrawal from the contract on transfer of business share, it may have implications for example on property area of third parties. They will not be entitled to require that the contractual parties exercise their right to withdrawal from the contract. It is impossible for third parties to achieve repayment of deposit for transfer of business share.

Act no. 246/2012 Coll. extended legal arrangement of $\$ 115$ Slovak Commercial Code to new sections (5-10) and in $\$ 117$ also added a section 4 . These provisions govern the condition of consent by tax administrator in the event of the transfer and division of the majoritarian business share. In respect to this the legislator introduced in section $7, \$ 115$ Slovak Commercial Code also the following legal definition of a majoritarian business share. ${ }^{38}$ Given the interpretation

38 For more see A. Palajová In Palajová A. - Poláček Tureková Z. Prevod a rozdelenie väčšinového obchodného podielu $\mathrm{v}$ spoločnosti $\mathrm{s}$ ručením obmedzeným a omeškanie dlžníka. In Zborník príspevkov z vedeckých seminárov katedier $\mathrm{v}$ akademickom roku 2012/2013 (z vedeckého seminára: Dopad hospodárskej a dlhovej krízy na postavenie podnikatelov). Banská Bystrica: Bankovní institut vysoká škola, a.s., zahraničná vysoká 
of legislator in the explanatory statement to the Act no. 246/2012 Coll., that the consent of the tax administrator with transfer or division of a majoritarian business share should be previous, so we assess this requirement as a condition for the validity of the legal acts. The failure of mentioned condition by the transferor and transferee causes absolute nullity of contracts on the transfer of majoritarian business share or contracts on the division of business share of a limited liability company on the basis $\$ 39$ Slovak Civil Code ${ }^{39}$. In this case alegal action is contrary to law by its purpose. I. Fekete ${ }^{40}$ explains that the law establishes rights and obligations only for the purpose, which is stated explicitly in the law or which it is clear from it ${ }^{41}$, but legal action followed a different purpose ${ }^{42}$. The effects of the transfer of majoritarian business share occurs under $\$ 115 \mathrm{sec} .10$ Slovak Commercial Code when the change in a person of member is entered in the Slovak Commercial register. Complications in changes concerning the company and its bodies may be caused at the time after the transfer of business share and before the registration of changes in member, by that the efficiency of transfer of majoritarian business share will relegate till the decision on registration of change of member. ${ }^{43}$

\section{Transfer of business share represented by a common certificate in limi- ted liability company}

Czech Business Corporations Act introduced option issue of securities in $\$ 137$ - common certificate, which will represent a business share in the company, if it will be so determined by the memorandum of association. The company may issue a common certificate for each business share, when is permitted formation of multiple business shares for one member according the memorandum of association. Condition for issuing a common certificate is that the business share to which should be common certificate issued didn't have limited or conditional transferability. A common certificate may not be publicly offered or admitted to trading on European regulated market or other public market by law.

škola, 2013. p. 145.

39 Act no. 40/1964 Coll. Civil Code as amended by Act no. 335/2014 Coll.

40 See Palajová A. - Poláček Tureková Z. Prevod a rozdelenie väčšinového obchodného podielu v spoločnosti s ručením obmedzeným a omeškanie dlžníka. In Zborník príspevkov z vedeckých seminárov katedier v akademickom roku 2012/2013 (z vedeckého seminára: Dopad hospodárskej a dlhovej krízy na postavenie podnikatelov). Banská Bystrica: Bankovní institut vysoká škola, a.s., zahraničná vysoká škola, 2013. p. 146.

41 As well as from $\$ 115 \mathrm{sec}$. 5 or $\$ 117 \mathrm{sec}$. 4 Slovak Commercial Code.

42 Legal significant purpose of legal act is that which is pursued by all the parties or at least one of them and the other parties are aware of this purpose, respectively this purpose must suppose, given the circumstances in which the legal act occurred.

43 See Palajová A. - Poláček Tureková Z. Prevod a rozdelenie väčšinového obchodného podielu $\mathrm{v}$ spoločnosti s ručením obmedzeným a omeškanie dlžníka. In Zborník príspevkov z vedeckých seminárov katedier v akademickom roku 2012/2013 (z vedeckého seminára: Dopad hospodárskej a dlhovej krízy na postavenie podnikatelov). Banská Bystrica: Bankovní institut vysoká škola, a.s., zahraničná vysoká škola, 2013. p. 146. 
Common certificate (will be applied on it otherwise provisions of the Czech Civil Code regulating securities $-\$ 514$ et seq.) is according to the Czech Business Corporations Act an order instrument and it cannot be issued as a book-entry security. Its requirements are defined in $\$ 138$ Czech Business Corporations Act. B. Havel ${ }^{44}$ to this legal arrangement notes that legislature followed the foreign experience and wording of draft regulation on the European Private Company. Author also points out that it isn't prohibited to issued business shares without common certificate and part of business share with them by the company. More or less, this decision will have a significant impact on the possible establishment of pledge on business share (different establishment is on business share without common certification - registration into the Companies Register and other is on business share such security - handover to the creditor that we can detect only if it is registered in the Register of Pledges). B. Havel also states that the Act does not prohibit the common certificates were the subject of a public draft contract pursuant to $\$ 322$ et seq., the public draft contract under the Act on transformations of business companies and cooperatives or public competition for the most suitable offer according to $\$ 1772$ et seq. Czech Civil Code.

Transfer of common certificate is regulated in $\$ 210$ Czech Business Corporations Act, but the basic rules as for other securities are included in the general provisions of $\$ 1103 \mathrm{sec}$. 2 Czech Civil Code. In view of mentioned condition for the issue of common certificate ( $\$ 137 \mathrm{sec} .2$ Czech Business Corporations Act) shall not be used on its transfer the provisions on transfer of business share to the other member ( $\$ 207$ Czech Business Act) and also on the transfer of business share on a person different from member $(\$ 208$ Czech Business Corporations Act), it will be used only the provision ( $\$ 209 \mathrm{sec}$. 1 Czech Business Act). Transfer of common certification - order instrument is by endorsement, the transferee shall accede to the company's memorandum of association a the transferor shall be liable to the company analogously under $\$ 209$ sec. 1 Czech Business Corporations Act. B. Havel ${ }^{45}$ comments that the Act does not suppose that the written contract should precede the endorsement, therefore it is sufficient only a contract concluded orally or impliedly, endorsement and handover of common certificate. Efficiency of transfer of common certificate between the parties occurs handover of common certificate, which was endorsed.The Act requires notice of change of member and the submission of the endorsed common certification to company (to check) for efficiency of the of transfer of common certificate towards company. Author concludes that the the transferor or transferee can make the notice but transferee - member submits the endorsed common certificate. Then the company shall update the list of members and the registration into Companies Register.

44 See Štenglová I. et al. Zákon o obchodních korporacích. Velký komentář. 1.vydání, Praha: C.H.Beck, 2013, p. 277.

45 See Štenglová I. et al. Zákon o obchodních korporacích. Velký komentář. 1.vydání, Praha: C.H.Beck, 2013, p. 403. 


\section{Conclusions}

The right to a stake represents partner's or member's property right in the company, which partner or member acquires when the company is incorporated. Partner or member as the owner of this other property value is entitled to dispose of his stake. The basic rules for its transfer are provided by provisions of Slovak Commercial Code or of Czech Business Corporations Act however, according to the stake linked with the concrete legal form of the company, these rules take into account the provisions of the Slovak Commercial Code, character of company and substance of its operation.

We consider the transfer of stake in a general commercial company for acceptable and we do not want the ban of this transfer like it is in the current Czech Act Business Corporations Act. We share the view of several authors that expression of (contractual) freedom of the person's will - future partner should be maintained not only when he "enters" to the company, as well as the partner decides to "withdraw" from the company. In any case, under difficult conditions than in other legal forms of companies. We propose in addition to the conditions set out in Slovak Commercial Code $(\$ 83)$ that the acquirer of stake in general commercial company should demonstrate scientific knowledge or skills, if the transferor of stake in general commercial company was the its bearer and are essential importance for fulfillment of specific business purpose of the company and it is strongly dependent on the particular composition of its partners (but we do not think of the person under $\$ 56$ sec. 4 Slovak Commercial Code).

Legislation of transfer of stakes in limited liability company has its basis in the Slovak Commercial Code and is stricter compared with the transfer of shares in joint stock company, which we perceive as reasonable given the small and limited number of members. Delimitation of the point in time of granting approval by the general meeting to the transfer of business share to another member or to third party lacks in Slovak legislation.We consider it is important that the general meeting expresses the consent (or disagreement) prior to the conclusion of the contract on transfer of business share with this transfer especially to a third party who is for other members less known and thus it is protected the interest of the whole company.The provisions about the period until which general meeting should grant the consent (or its denial) with transfer of business share are absent also in Slovak legal adjustment. It would be appropriate to modify the legal options in the form repudiation the contract on transfer of business share that acquirer would apply in the case of withholding of approval. Inspiration could be an actual Czech legislation in the Business Corporations Act, which alleviates transfer of business shares facilitates the most towards "openness" of limited liability company (also by regulation of transfer of common certificate incorporated into business share), but it maintains the possibility to conclude company. 